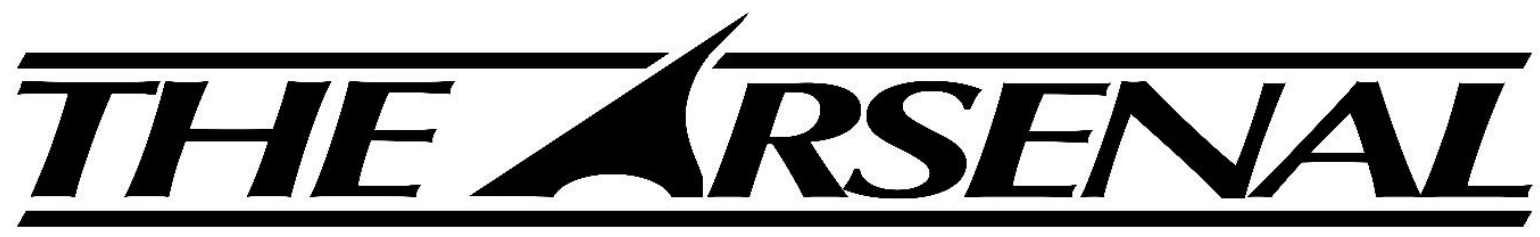

Augusta University's Undergraduate Research Journal

ISSN 2380-5064 | The Arsenal is published by the Augusta University Libraries | http://guides.augusta.edu/arsenal

Volume 3, Issue 2 (2020)

Special Edition Issue

THE PAST IS A FOREIGN COUNTRY THEY VIEW

THINGS DIFFERENTLY THERE: THE PERCEPTION

OF "THE INVISIBLE EMPIRE OF THE KU KLUX KLAN"

AS A BENEVOLENT SECRET SOCIETY FROM 1915 TO 1965

Dillon Typhair and Ruth McClelland-Nugent

\title{
Citation
}

Typhair, D., \& McClelland-Nugent, R. (2020). The past is a foreign country they view things differently there: The perception of "The Invisible Empire of the Ku Klux Klan" as a benevolent secret society from 1915 to 1965. The Arsenal: The Undergraduate Research Journal of Augusta University, 3(2), http://doi.org/10.21633/issn.2380.5064/s.2020.03.02.46

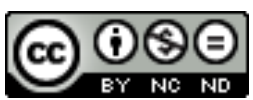

(C) Typhair and McClelland-Nugent 2020. This open access article is distributed under a Creative Commons Attribution NonCommercial-NoDerivs 2.0 Generic License (https://creativecommons.org/licenses/by-nc-nd/2.0/). 


\section{The Past is a Foreign Country They View Things Differently There: The Perception of "The Invisible Empire of the Ku Klux Klan" as a Benevolent Secret Society from 1915 to 1965}

Presenter: Dillon Typhair (Poster Presentation)

Authors: Dillon Typhair and Ruth McClelland-Nugent

Faculty Sponsor(s): Ruth McClelland-Nugent, $\mathrm{PhD}$

Department Affiliation: History, Anthropology, \& Philosophy

\section{ABSTRACT}

This presentation looks at the history of Americans' changing attitudes toward the $\mathrm{Ku}$ Klux Klan, and contributes to the scholarship on Civil War history and domestic terrorism through the case of the KKK. The journalist Edward Pollard's book, The Lost Cause: A New Southern History of the War of the Confederates (1867), influenced generations of Americans both south and north by writing a revisionist history of the Civil War, painting confederates as rebels who should still fight to maintain white supremacy. The belief in this "lost cause" led many Americans, in the south especially, to support and have positive attitudes toward the KKK. However, even as the Klan claimed to support the ideals of the "lost cause," their actions often undermined their claims of benevolence and of upholding southern value. The Klan, especially after its revival post-WWI, terrorized anyone they deemed not "pure American" through violent acts. Today, it is unlikely that the Klan will ever be positively regarded as it once was, even if similar hate groups still plague society. 